\title{
Language, education and the peace process in Myanmar
}

\section{Introduction}

This Article explores how language and education have featured in half a century of armed ethnic conflict in Myanmar (Burma), how these issues feature in the on-going peace process, and how an exploration of key actors' positions in relation to language and education can help to better understand the underlying dynamics of conflict, and the still highly contested peace process. Given the salience of ethno-linguistic diversity in Myanmar (Smith 1999, South 2008), studies of the politics of language are surprisingly thin on the ground. (Important exceptions include Callahan 2003, Salem-Gervais \& Metro 2012, Lall and South 2013). While the complex and fastchanging peace process in Myanmar, which emerged in late 2011, has yet to generate much scholarly analysis, commentary and policy literatures have largely bypassed the relationship between language, education and state-society and armed conflicts, and their resolution.

Thus far, those engaged in the broader movement of political reform in Myanmar have largely addressed education and peace-building as separate issues; likewise, state, international (donor) and other actors in the peace process have mostly ignored issues of language and education. This article explores the relationships between education and language policy and practice, and armed conflict and - more recently the peace process in Myanmar. We focus on the state education system, and education regimes under the authority of three major Ethnic Armed Groups (EAGs) - one of which (the New Mon State Party: NMSP) has maintained a ceasefire with the government since 1995, one (the Kachin Independence Organisation: KIO) which saw its 17 year ceasefire collapse in 2011, and the third (the Karen National Union: KNU), which in early 2012 agreed a preliminary ceasefire, following more than half-acentury of armed conflict. Analysing these two contrasted case studies (and addressing the situation of other ethnic communities, as necessary and in order to provide context) allows us to draw out questions regarding the relationship between ethnic nationality communities and the state, concluding that a sustainable resolution to Myanmar's long-standing ethnic conflicts will be difficult to achieve without education reform that addresses the right language policies.

The article is based on background data collected over a period of 9 months of fieldwork in 2011. ${ }^{1}$ The results of this research were published (Lall and South 2014) and as the peace process gathered pace and increased in complexity the team decide to return to the field in 2015 . $^{2}$ Data was collected in Mon, Karen and Kachin States, and the team spoke to 55 people and conducted 21 focus groups and larger meetings with stakeholders from EAGs, EAG education departments, ethnic political parties and local civil society groups (including ethnic NGOs). In addition teachers, parents and students at ethnic schools were either interviewed or took part in focus groups. ${ }^{3}$

\footnotetext{
${ }^{1}$ The 2011 research was funded by the PERI fund of OSI.

${ }^{2}$ The 2015 research was funded by DAI (USAID).

${ }^{3}$ Given the sensitive nature of the research, and at the request of several interlocutors, the team cannot divulge the names of these individuals or organisations.
} 


\section{The conflict nexus and the peace process; Language rights, and the politics of education}

Myanmar is home to more than 100 ethno-linguistic groups, with a population of over 51 million. Non-Burman communities make up at least $30 \%$ of the population.

In the lead-up to independence in 1948, ethnic nationality elites mobilised communities in order to gain access to political and economic resources, demanding justice and fair treatment for the groups they sought to represent. The KNU went underground in January 1949, initiating more than six decades of (mostly 'low intensity') civil war. The ensuring armed conflict was marked by serious and widespread human rights abuses on the part of both the Myanmar Army and - less systematically - EAGs. Myanmar's ethnic insurgents have been fighting to achieve political self-determination, which in recent years has been framed as a desire for federal autonomy within a multi-ethnic Union (Smith 1999); unsurprisingly, after half a century of armed conflict, there are also significant political-economic agendas at play in Myanmar's armed conflict, and peace process.

For decades, communist and dozens of ethnic insurgents controlled large parts of the country. Since the 1970s however, armed opposition groups have lost control of their once extensive 'liberated zones', precipitating humanitarian and political crises in the borderlands. A previous round of ceasefires in the 1990s brought respite to conflictaffected civilian populations, and provided the space for civil society networks to (re-) emerge within, and between, ethnic nationality communities. However, the thenmilitary government proved unwilling to accept EAGs' demands for substantial political negotiations. Therefore, despite some positive developments, the ceasefires of the 1990s did not dispel distrust between ethnic nationality communities and the government (South 2008).

A new phase in the peace process began in late 2011, under the military-. backed, semi-civilian government of U Thein Sein. Preliminary ceasefires were agreed with most (but not all) of Myanmar's EAGs, and some progress was made towards negotiating a comprehensive Nationwide Ceasefire Agreement (NCA). At the time of writing however, progress seems to have stalled, with significant differences remaining between EAGs and the government (and particularly Myanmar Army) on a range of issues, including Security Sector Reform, and how to decide the future political make-up of the country. With elections scheduled for November 2015, it seems unlikely that the peace process as currently configured will result in a comprehensive settlement. Myanmar's next government will have a packed agenda, and may not prioritise the peace process in the same way as its predecessor. The concerns and aspirations of ethnic nationality communities will not go away, but the opportunity to address these through a structured peace process may be diminishing. Although, at the time of writing, election campaigning had not yet begun, the country's two main political parties - the governing Union Solidarity and Government Party (USDP), and opposition National League for Democracy (NLD) - have demonstrated limited interest in mother tongue schooling and ethnic education. Ethnic-based political parties did relatively well in the 2010 elections, but will struggle to prevail in 2015, against the well-resourced USDP and the highly popular NLD (or at least its leader, Daw Aung San Suu Kyi). Therefore, while ethnic political parties are important champions for mother tongue and ethnic education in Myanmar, 
EAGs and civil society actors are likely to remain key actors in this field - despite the uncertain progress of the peace process.

Meanwhile on the ground, the peace process is seen by some stakeholders as a vehicle for the expansion of militarised state structures into conflict-affected areas, where the government is experienced by local communities as illegitimate, predatory and violent. This is the case also in the field of education.

The right to 'mother tongue' language education has been at the heart of Myanmar's prolonged state-society and armed ethnic conflicts. At a minimum, ethnic nationalists have demanded the teaching of minority languages in schools (including state schools); a stronger version of this position is to demand teaching of the curriculum in the mother tongue (at least through primary schooling). Positions in relation to language use (in schooling, and more broadly in public administration) can provide a mapping of ethnic nationalist elites' (civil society actors, political parties, and particularly EAGs) positions, vis-à-vis conflicts in Myanmar more broadly. The stated positions, and practices, of key stakeholders (e.g. EAGs, and affiliated and associated education actors) derive from and reflect (and to a degree inform) identities, interests and positions in the broader peace process. Different actors' positions on the relationship between EAG education systems and those of the state (as discussed below), and demands regarding the use of ethnic nationality languages in (for example) the administration of government and justice, can be seen as proxies indicating how stakeholders consider that Myanmar's ethnic communities should relate to the state - revealing a continuum of positions, from unitary state-led assimilation of minority communities, through varying types of federalism, towards outright secession and independence for ethnic polities.

Thus, language policies are not linked only to learning and cognition in schools. In many developing countries, especially nations made up of diverse ethnic groups and subject to state-society (including armed) conflict, there tends to be a concern among state authorities that promotion of minority languages and ethnic identities will lead to greater divisiveness (the literature is discussed below). Government and non-state educational regimes often use language policy to serve an instrumental purpose, such as building a national identity. This can discriminate against 'others', including vulnerable minority groups, and can lead to resentment, resistance and conflict. Education and language use in these cases underpins, and even causes conflict between the majority and minority groups.

In Myanmar, half a century of military rule (between 1962-2011) saw the consolidation of state power under a regime identified with the Bamar (Burman) ethnic majority, which makes up about $60 \%$ of the population (Houtman 1999). During this period, Burmese (the majority language) became the sole language of governance and education, with ethnic minority (or 'ethnic nationality', as many groups prefer to be designated) languages suppressed and marginalised. The perceived 'Burmanisation' of state and society has constituted one of the prime grievances of ethnic nationality elites, which have mobilised minority communities to resist militarised central government authority, in the context of the world's most protracted armed conflict (Smith 1999, South 2011). 


\section{Language, education and conflict literatures, in the Myanmar context}

Education is often projected as a panacea to conflict. However, a limited set of literature engages with how education is not only a (potential) part of the solution, but often a part of the problem as well. Smith \& Vaux (2003: 2) develop Bush and Saltarelli's analysis (2000) to reflect on the role of education in "political and social processes", stressing the "active rather than passive role" (2004: 19) that education plays in causing conflict. Smith \& Vaux (2003) also examine key aspects of education systems that can be implicated in the push towards, or pull from, conflict. This is a useful structure when looking at how education in Myanmar has contributed to conflict.

Curriculum: particularly the way in which it deals with issues of identity - e.g. language, religion or culture. Both the Myanmar government and some EAG education departments have used the curriculum as a political tool to shape identities (see below). In fact, many young Bamar think that in order to be Myanmar you have to be a Buddhist - a result of that legacy. (Lall et al. 2014)

Language: "The role and status of [minority] languages ... may lead to tensions" (Smith \& Vaux 2003: 29). By banning the use of ethnic languages in state schools in the 1960s, the government set the scene for major grievances that fed into the conflict between the Tatmadaw (Myanmar Army) and EAGs, and the broader ethnonationalist community. To this day, the status of ethnic nationality languages in state schools remains fiercely debated.

Religion: Tensions can arise over state funding of religious schools, the unequal provision of resources to schools serving different faiths or denominations, or the reinforcement of a sense of difference or even antipathy. The Myanmar government has not supported religious schools as such, although more recently the Ministry for Religious Affairs has helped with teacher salaries at Monastic schools. Monastic schools, however, accept children from other religions, in addition to the Theravada Buddhist faith of the majority population. ${ }^{4}$ Historically, religion has not featured significantly in armed ethnic conflicts in Myanmar (beyond the case of Kachin State, where insurgency broke out in the early 1960s, in response to government's sponsorship of Buddhism as the state religion: Smith 1999). However, given the changing scenario with regard to the sangha's (Buddhist monkhood's) voice and positions on identity, and the recent upsurge in popular Buddhist nationalism (and anti-Muslim violence) in Myanmar and the region, issues of religion and religious education seem increasingly to be implicated in conflicts in Myanmar.

Culture, History, Geography: What form of 'national identity' is presented through these subjects? Are differing perspectives represented or subordinated? As discussed above, history and geography to date have not been context specific, and children in government schools in ethnic states only learn history as seen through a Bamar lens.

Resources, Textbooks, Media: Referring to the political/ideological messages that are being promoted through textbooks,- which have for decades emphasised the martial tradition, nationalism and militarism, portrayed as essentially linked to a Bamar identity (Lall, M. and Hla Hla Win 2013), targeted at the ethnic minorities, as a form

\footnotetext{
${ }^{4}$ This can also be a source of resentment - perceived Burmanisation of minority children through monastic education.
} 
of attempted assimilation.

Teachers, Teacher Education and Teaching Methods: As teachers are central to education systems, the transmission of the curriculum is affected by the way the teacher teaches. Having mainly Bamar government teachers in government school in ethnic states is likely to have contributed to the widespread sense of alienation felt among minority communities. However, no on the ground research has been done on this.

Peace Education: Referring "to the process of promoting the knowledge, skills, attitudes and values needed to bring about behaviour changes that will enable children youth and adults to prevent conflict and violence, both overt and structural" (UNICEF working paper, cited in Smith \& Vaux, 2003). There has been no formal (and little informal) peace education in Myanmar to date, with few programs emphasising community cohesion. Whilst such developments may emerge as a part of the reform process underway in Myanmar, they are not as yet in place. Under decades of military rule, people living in government-controlled parts of the country were denied access to reliable news, or impartial assessments of conflict issues. Indeed, Bamar-majority communities often have little understanding of the realities experienced by their ethnic minority brethren, particularly in conflict-affected areas. Given their lack of information regarding ethnic aspirations and grievances, there is a risk of Bamarmajority communities being mobilised by unscrupulous politicians to oppose possible political changes in Myanmar (e.g. re-structuring the state along more federalist lines), as a result of negotiations related to the peace process. Widespread antiMuslim prejudice and violence has demonstrated the propensity of elements of the Buddhist-Bamar majority to being mobilised "in defence of race and religion". Thus the importance of peace education, in order to prepare the majority community for possible socio-political (and political-cultural) changes in the context of the peace process.

Educational reforms and structural adjustment: Smith \& Vaux (2003: 36) propose a Sector Wide Approach to educational reform that is based on a "comprehensive overview and conflict analysis of the whole education sector". Whilst an education review is in place in Myanmar, and is likely to lead to education reform, this process has not been inclusive of the ethnic minority education groups. There has been no engagement with the issue of conflict within this review.

The 2011 Global Monitoring Report (UNESCO, 2011a) summarises what has plagued Myanmar's education system for 6 decades: "Schools as a vehicle for social division" (2011a: 167), through the imposition of a dominant language, the manipulation of textbooks to encourage intolerance, the championing of a culture of violence, and segregation.

However, schools are not the only vehicle through which conflict has been fuelled. Brown (2011) describes education's structural and socio-economic influence on conflict, whereby inequalities between groups are created and maintained, and the political effect whereby divisions are reinforced through segregation and political exclusion of particular groups. He mentions the issue of education raising aspirations that may then lead to frustration when opportunities are unavailable. 
Brock (2011: 29) recognises the "potential for education to exacerbate the endemic cultural conflict that is inherent in the human species". He differentiates between 'conflict within education' and 'education within conflict'. Conflict within education (Brock, 2011) refers to the struggle over political control of what happens in schools. Brock cites several ways in which education systems themselves become sites of conflict, including disputes over language of instruction. As discussed below, in the context of the peace process, education in Myanmar has become a site of contest, with state and non-state actors competing for authority over teaching institutions and curricula, especially in armed conflict-affected areas.

'Education within conflict' (Brock, 2011) refers to the contribution that education makes towards creating and sustaining conflict - e.g. through the manipulation of curricula to promote jingoism or ethnic hatred. Both state and non-state curricula in Myanmar have contributed towards "othering" of enemy communities and structures, exacerbating and deepening identity conflicts. He also examines education and conflict in the broader sense of the term by exploring 'education and socio-cultural violence', by which he refers to the symbolic violence imposed on women by patriarchal oppression and 'education and environmental conflict' i.e. the role that education has in creating or resolving conflict that human beings have with their environment.

The UNESCO Global Monitoring Report (UNESCO, 2011a: 131) recognises the role that education can have in contributing to conflict; "Education systems do not cause wars. But under certain conditions they can exacerbate the wider grievances, social tensions and inequalities that drive societies in the direction of violent conflict". While acknowledging that education can and does contribute to conflict (Chapter 3), the 2011 Global Monitoring Report also acknowledges the role that education has in peace-building (Chapter 5). It identifies a number of dimensions, including through mother-tongue education and the acceptance and use of minority languages in schools (2011a: 241-42), the reform of history and religion curricula to represent multiple perspectives (242-45), developing inclusive curricula for peace and citizenship education (245-46), integrating children from different groups into multi-ethnic/faith schools (246), devolving school governance (246-248) and ensuring that schools themselves are free from violence (248-49). Clearly whilst education has been part of the conflict scene, it now needs to be a part of peace-building in Myanmar - a platform where government and EAG can come together and build something new.

\section{Language rights and education before 2011}

For decades, the Myanmar state education system has insisted on Bama saga (Burmese) being used through a national school system, to create a Myanmar national identity based on Bamar culture, with Burmese as a "unifying", language (Callahan 2003, Watkins in Simpson 2007). Given the diversity of ethno-linguistic groups in Myanmar, there is a strong argument for the country having a 'lingua franca' or Union language. ${ }^{5}$ However, the promotion of Burmese as a national language under the previous military government has not led to an inclusive national identity, as ethnic groups were still discriminated against, and the 'national identity' that was promoted was strongly identified with the Bamar majority ethnic group (Houtman

\footnotetext{
${ }^{5}$ This is not unusual in countries with different ethnic and linguistic groups - see Pakistan and Indonesia for example.
} 
1999). Bush and Saltarelli (2000: vii) examine both "the constructive and destructive impacts of education": how it both can contribute to, and/or mitigate violence and conflict. Education contributes conflict, not only through the unequal distribution of education among ethnic groups but also through educational policies that undermine or even erase a particular culture, particularly through the imposition of a dominant language as language of instruction. The perceived forced assimilation policy of 'Burmanisation' was greatly resented by most ethnic stakeholders, and drove waves of ethnic minority citizens into revolt against the government - further polarising and propagating armed conflicts across the country.

In contrast to formal (state-controlled) schooling, ethnic nationality civil society actors in government-controlled areas - particularly faith-based networks (e.g. Karen and Kachin Christian churches; Mon and Shan Buddhist monasteries) - have long struggled to provide ethnic language teaching outside of school hours, often in informal settings under threat of state suppression (South 2008, Lall and South 2013). Various ethnic literature and culture committees (some of which were established in the 1950s, although most of these were semi-dormant in subsequent decades), supported the expansion of ethnic language literacy programs in the 1990s. Although these (Shan, Mon, Karen, $\mathrm{PaO}$ etc) groups have done much help to keep ethnic culture alive, they cannot substitute for regular (formal) schooling. In areas more directly affected by armed conflict, and particularly in EAG-controlled zones in the borderlands, non-state actors developed their own education regimes. Some were fairly closely modelled on the state school system curriculum, whereas others developed along separate (indeed, particularly from the 1960s through the 1970s, separatist) lines, using mother tongue education to promote and reinforce ethnic nationality ethnic identities, and opposition to the militarised state. It is important to note that the various EAG education systems differ markedly from each other, both in terms of the language they use but also based on what curriculum they chose to teach.

Ceasefires in Mon and Kachin states - parallel mother tongue education with links to the state system

The KIO and NMSP agreed ceasefires with the then military government in the mid1990s. For a decade and a half, both groups maintained an uneasy truce, which allowed for the limited rehabilitation of conflict-affected communities and the (re-) emergence of rich civil society networks, within and between ethnic nationality communities in Myanmar. Most commentators have regarded the ceasefires of the 1990s in Myanmar as a failure, as they did not result in political negotiations to address the social, political, economic and cultural issues underlying decades of armed conflict in the country. Nevertheless, in the context of the previous round of ceasefires, the KIO and NMSP (and some other groups) expanded their already existing education networks, to provide mother tongue teaching to children in their areas of control ('ceasefire zones') and in adjacent government-controlled areas. The EAG-aligned education providers, like the Mon (NMSP Education Department: Mon National Education Committee/Department) and the Kachin (KIO Education Department) have used the government curriculum in translation, combined with additional elements teaching ethno-national history and the mother tongue. Their schools allow for children to learn Burmese as they grow older, so that they can join the government education system either at middle or high school level, and then go on to state tertiary education institutes, if they so wish (and can afford to). Whilst primary school education is conducted in the mother tongue, and older students 
continue to study their mother tongue and ethnic history alongside the Myanmar national curriculum, these groups generally perceive the value in an education system that does not separate and isolate their young people from the rest of the country. The Mon national schools represent a positive conceptualisation of the relationship between a locally owned and implemented education system which preserves and reproduces ethnic national identity and language, and linkages to the central government/Union education system. As such, the Mon national education system may be seen as an incipient approach to building federalism in Myanmar, 'from below' - or from the bottom, up.

Continued conflict in Karen state - parallel mother tongue education with a separatist identity

The main Karen armed group - the KNU - did not agree a ceasefire in the 1990s. The Karen education system, which for understandable historical reasons has evolved as a more-or-less separate regime, producing graduates (many of whom actually studied in refugee camp schools, in neighbouring Thailand) who are being educated into (virtual) citizens of a putative Karen free state (Kawthoolei), rather than of the Union of Myanmar. This means that they are unable to reintegrate into the Myanmar government education system. The KNU education system emphasises a clearly articulated Karen (separatist?) identity, with regard to the Bamar-dominated society. Karen national school graduates tend to speak little Burmese, and while they may be exposed to high quality teaching (in at least some schools), this cohort receives qualifications that are not recognised in Myanmar or any other country. Although many Karen schools in conflict-affected (and especially in government-controlled) areas in practice adopt 'mixed' curricula and teaching practices (Lall and South 2013), the Karen national school system nevertheless represents an alternative model of ethnic nationality education in Myanmar, quite distinct from the state system.

\section{The new government and the reform process}

The election of a military-backed, semi-civilian government in November 2010 represented a clear break with the past. The new government initiated a multipronged reform process that included reconciliation with the NLD, economic and education reforms as well as a peace process with the EAGs. In late 2011 and 2012, preliminary ceasefires were agreed between the government and most Ethnic Armed Groups (EAGs). The peace process has seen the lives of conflict-affected civilians undergo profound transformations for the better. The Myanmar Peace Support Initiative (MPSI 2014) conducted a 'listening project' with conflict-affected communities in remote parts of Myanmar, to listen to Karen, Mon and Karenni (Kayah) communities particularly women - experiences before and after the ceasefires. Initial findings indicate that many people have benefited greatly from preliminary ceasefires between the government and the KNU, New Mon State Party and Karenni National Progressive Party. For example, before the KNU ceasefire, villagers often had to flee from fighting, and to avoid forced conscription and portering. Post-ceasefire, people report greatly decreased levels of fear. In some cases, displaced people are beginning to return to previous settlements and attempting to rebuild their lives. In many communities, livelihoods have improved as a result of villagers' better access to their farms, and a reduction in predatory taxation. Nevertheless, civilians fear a breakdown in the peace process, and resumption of armed conflict. 
To date questions of ethnic language and teaching regimes have not featured prominently in negotiations despite the fact that the use of mother tongue in schools in ethnic areas is one of the original grievances that fuelled the conflict. One reason why language and education issues have not featured significantly in the Myanmar peace process thus far, is because this has to date been a largely elite-driven exercise, involving the Myanmar government (more recently, with significant input from Myanmar Army) and EAGs - with little involvement from civil society groups or political parties, beyond networking and advocacy activities. As the peace process moves into next phase of widely anticipated political negotiations, discussions and demands regarding education and language use are likely to become more prominent within the peace process.

However the government has already launched an education review and reform process that has been totally disconnected from the peace process. Ethnic educators have so far had had very little input into the education reform processes. The government started by increasing spending on education to around 5\% of the 2013/14 Union budget and increased teacher salaries (especially for those working in remote, conflict-affected areas) as well as providing direct small grants to schools for repairs. A new education 'mother law' was passed in parliament, resulting in mass protests on the streets by students who believe that the government retains too much control over education matters. Much of the education argument is around decentralisation and local power and whilst there has been some discussion around this, it remains unclear whether this will mean a fiscal decentralisation, and at what level (State/Region or Township) policy decisions will be made. ${ }^{6}$ The hope is that if education policy decisions are decentralised to state governments to at least a limited level in the future, that state parliaments will be able to engender a debate on issues of language and culturally and context adapted curricula. Already, State/Region governments in a number of areas (Mon, Bago and Tanintharyi) have begun to introduce minority languages into government school curricula at the primary level. This has been as a result of pressure both at the Union level (from the executive, and particularly on the part of ethnic nationality parties in Parliament), and due to activism on the part of

\footnotetext{
${ }^{6}$ November 2012 Draft Framework for Social and Economic Reforms (FESR), quoted below, indicates that the GOM plans to work with a distributed (or deconcentrated) model of education management. "GOM attaches high priority to developing a participatory process of local budgeting, which should reflect local priorities and needs while corresponding with national policy directions, by delegating decision-making authority over expenditure compositions (between recurrent and capital expenditure) as well as inter-sectoral allocations (between sectors) under the guidance of local parliaments. However, GOM still retains the budgetary controls over health and education expenditure for transitional adjustments, which may be a future subject of decision for fiscal decentralization. In the meantime, GOM plans to ensure that the initial imbalances of decentralization can be corrected through a gradual process of coordination and delegation, which can ultimately reinforce the legitimacy and capacity of the state and regional governments particularly for those that are contributing to parallel process of peacebuilding and regional development." (FESR, November 2012 Draft, page 34, emphasis added) ..."While GOM strengthens regulatory policies to streamline various private and community-run educational programs, it is also moving ahead with the decentralization of education management in line with the requirements of the Constitution by integrating locally-designed teaching curriculum as well as non-formal programs in basic education system. This reform policy and strategy will focus on the need to expand the system of basic education from eleven to twelve years, on child-centred teaching methodologies, upgrading teacher training and other curriculum reforms necessary to enhance the quality of basic education, on teacher remuneration and broader issues of education financing, on establishing a rigorous system for education quality assessment and performance, and on further reforms in the management of basic education including the importance of active engagement in the process by the parents themselves. In addition, GOM will also pay attention to other supportive measures that can address high drop-out rates and out-of-pocket cost burdens on the families." (FESR, November 2012 Draft, page 29,)
} 
civil society and political parties at the State/Region level. However, such initiatives remain under-resourced, in terms of the availability of mother tongue-speaking teachers and funds to pay them, and in regard to the limited supply of quality teaching materials. In this context, there is a risk that state schools newly required to teach minority languages may 'poach' teachers from EAG and other locally owned and delivered education systems - a development which would exacerbate conflict, instead of than addressing one of the key grievances of ethnic communities.

\section{Language rights and education in the reform era}

At the time of writing, ethnic educators have yet to develop a common position regarding mother tongue usage in education, although such a policy might be emerging. ${ }^{7}$ Given the difficulty which EAGs (which are often internally fragmented along ideological, personality, clan-based and political-economic lines) have encountered in developing common positions and strategies to engage constructively with the government (in Myanmar Army) in the peace process, it is not surprising that diverse (and sometimes fractious) ethnic elites have yet to develop a coherent and comprehensive set of policies in relation to education.

Most ethnic educators and political elites seem willing to acknowledge that Burmese (Bama saga) is and should continue to be a Union (national) language (perhaps together with English). They are though concerned that ethnic languages should be given equal status, particularly in ethnic nationality-populated areas (and especially the country's seven ethnic States) - both in schooling, and in general administration. However, serious debates remain regarding the status of the languages, cultures (and by proxy, political legitimacy) of 'minorities within minorities' - such as for example the $\mathrm{PaO}$ in Shan State, Pwo (Ploung) and other Karen sub-groups, and the situation of Karen communities in Mon State and elsewhere (e.g. Bago and Irrawaddy Regions). It seems unlikely that well-established ethnic minority communities, some of which have historically experienced conflictual relationships with neighbouring (sometimes larger) ethnic nationality groups, would be willing to allow their ethnic brethrens' language to become the dominant medium for schooling and/or governance, at the State-level - potentially consigning smaller minorities' languages and cultures to further marginalisation. The gap is also wide on positions regarding the role of the state. Whilst some who teach the government curriculum would like to see some financial support from the state (without losing their autonomy), others do not want any association with the government education system at all.

The role of renewed conflict in Kachin state - disengaging the education system from the state

In June 2011 the KIO ceasefire broke down, leading to a return of widespread armed conflict, with associated human rights and population displacement. In consequence, the KIO education system has been disengaged from the state system, with Kachin nationalist educators now pursuing a more avowedly separatist agenda, similar to that which has characterised the KNU education regime.

\footnotetext{
7 'Its MINE: Indigenous groups claim their rights through new network for education in Myanmar' (press release on International Mother Language Day, 21 February 2014).
} 
Direct results of the conflict include a disengagement from the state system and a rejection of using Bama saga as a medium of instruction. ${ }^{8}$ Different Kachin groups are now actively involved in developing a new curriculum in Jingpaw that they feel is more appropriate for Kachin children. Content, language of instruction and teaching method are being changed in a process that sees educators develop the new curriculum as children progress through schools. Whilst there is an acknowledgement that the lack of accreditation will create a problem for students (in that they will no longer be able to move back into the Myanmar state system), the majority of those involved in education across Kachin State maintain that the quality of existing system is so low, that no parents would want their children to study at a Myanmar university anyway. Many also promise that solutions to those problem will be found in time. A few interlocutors acknowledge that the education reforms in Myanmar might result in a better system that the Kachin children should have access to, but these voices few, and generally many maintain that they do not trust the reforms will be successful, or if they are, relevant for Kachin students.

\section{The role of continued ceasefire in Mon state - rapprochement?}

Despite political difficulties, the NMSP ceasefire has persisted, and was renewed in February 2011. Although the current peace process in Myanmar remains problematic, the persistence of the NMSP ceasefire provided a unique space for the Mon education system to flourish. However, disappointed by a lack of donor support for a system widely regarded as a model of best practice for ethnic education schooling in Myanmar, NMSP educators are faced with a dilemma: whether to embrace a closer relationship with the (reforming) state education structure, or to follow the Kachin model, and retrench as separate education system. The government (at Union and Mon State levels) has recently passed legislation and made statements, allowing for and indeed encouraging mother tongue education in ethnic nationality-populated areas, at primary level. As state schools are not well equipped to deliver these services (lacking appropriate teaching materials, or qualified teachers), an opportunity exists for Mon educators to 'fill the gap', and receive state (and presumably donor/international) recognition and support for their work, ensuring the long-term viability of the Mon education system. The Mon nationalist community, generally wants the MNEC to remain independent of the state system during the transitional period of the peace process - only considering integration with the government school system a viable option after a comprehensive political settlement is agreed. Although these issues and positions are contested, the majority of Mon nationalism and educators (including the MNEC) want to expand the use of Mon in government and 'mixed' schools, and eventually see a structured interaction and convergence between state and non-state education systems. Unfortunately, donors to the peace process have been reluctant to support this model of best practice.

Like KIO school graduates until the resumption of armed conflict in $2011,10^{\text {th }}$ Standard MNEC students can sit government matriculation exams, and join the Union higher education system (should they choose to do so, despite its faults). Thus, ethnic minority children receive the benefits of mother tongue schooling, but are still able to position themselves as citizens of a multi-ethnic Union (including through the possession of Burmese language skills). While Mon school system has retained these

\footnotetext{
${ }^{8}$ This happens to be a 'mutual rejection' as the conflict has also resulted in a recent government decree refusing to let children from KIO administered schools transfer to government schools, something they had previously been able to do.
} 
characteristics (despite the MNEC's struggles to secure adequate funding), the breakdown of the KIO ceasefire in June 2011 has led to a dis-engagement between the Kachin and government school systems, in the context of significant alienation and anger on the part of the local community. Kachin education (including the KIO school system) seems to be diverging from the government system, and adopting some of the 'separatist' characteristics demonstrated by the Karen (KNU) system.

\section{The role of a new ceasefire in Karen state - ways forward?}

Meanwhile, the KNU and associated education actors are undergoing a profound review of their education experience and regimes. The KNU education system is a remarkable testimony to the resilience and commitment to education of Karen communities. Nevertheless, in order to be viable in the long term, this regime will need reforming, including particularly strategic re-imagining of the relationship between the Karen and state education regimes, in terms both of syllabus and administration. In the broader peace process, the KNU has been the most pro-active and creative of the nearly 20 Ethnic Armed Groups involved in peace talks with the government.

As the political realities change on the ground, a few families have tried to relocate back from the camps and the border to government controlled areas. They have found it difficult to get their children into government schools due to a language barrier. Unsurprisingly the Karen families interviewed in a micro study ${ }^{9}$ said it depended upon the good will of the local head teacher and the patience of the teachers. The government administered placement tests were perceived as unfair to children who have studied a very different curriculum. At the time of writing a number of NGOs are trying to work with the government on a system that would allow children to transfer between systems and schools, although everyone is aware that there is a long way to go.

In a positive development (which contrasts to the Kachin expense), Karen educators have in the context of the peace process begun to reconceptualise and negotiate the relationship between their schools and those of the state. On the ground, implicit and explicit contests are playing out between a state school system perceived as pushing into previously inaccessible, armed conflict-affected and ethnic nationality-populated areas, and a resilient and locally legitimate KNU-oriented school system. Scope exists within formal political negotiations in the peace process for a negotiated 'convergence' between the KNU and government school systems (Joliffe 2015). In order to be successful and comprehensive, such discussions should be explicitly included on the agenda of peace talks (perhaps in the forthcoming political dialogue phase), rather than remaining ad hoc and peripheral to the main peace process.

\section{Discussion}

Based on a combination of primary research and literature review, we have shown how language and education policy and practice are deeply implicated in ethnic conflicts in Myanmar. Since at least the advent of military rule in 1962, the state has been perceived - with justification - as pursuing a more-or-less explicit and conscious project of forced assimilation vis-a-vis the ethnic nationality communities. Ethnic

\footnotetext{
${ }^{9}$ Small study and presentation by Save the Children, Myanmar Conference Chiang Mai July 2015 - need to get report from them.
} 
nationality elites (EAGs and civil society actors) have resisted 'Burmanisation' through a number of strategies, including armed conflict, and the development of education regimes which preserve and reproduce their languages and cultures.

The existence of EAG ethnic education systems demonstrates the importance which ethnic communities and leaders place on mother tongue education - their persistence and resilience ('social capital'). These systems were developed during years of protracted armed conflict, prior to ceasefires in Myanmar in the 1990s. In the context of their respective ceasefires (in 1994 and 1995), the KIO and NMSP expanded their education systems, achieving what might be considered a form of 'federalism from below' in Myanmar. Despite great difficulties in securing resources (both financial, and human), the KIO and NMSP school systems were locally owned and delivered, and supported mother tongue teaching, particularly at primary level. In the absence until recently - the a Karen ceasefire, the KNU Education Department (with support from international NGOs) developed an impressive education system well-suited to local needs, which diverged significantly from the government system, not least through the promotion of Karen language and culture/identity, with only a limited focus on Burmese language (Bama saga).

Through their promotion of local languages, these schools address one of the key demands of ethnic minority communities in Myanmar: the maintenance and teaching of ethnic languages, under conditions of local control and administration - i.e., selfdetermination in the field of education. These struggles have significance beyond the fields of education and schooling. Positions in relation to language and education policy - including especially the appropriate medium/s of instruction - indicate (or reflect) the identities and interests of different stakeholders, in terms of the kind of country they imagine Myanmar to be, and via-a-vis the peace process. Debates regarding the status and future of ethnic education reveal positions regarding the appropriate relationships between State and Union governments and ethnic nationality polities. Since at least 1962, the government has sought to bring ethnic nationalities under direct central control, denying autonomy to ethnic communities, including in the fields of education and language use (or at least teaching in schools). In this historic context, where the military-dominated state has denied and suppressed demands for a federal settlement to Myanmar's state-society and ethnic conflicts, local efforts to promote self-determination in the field of education (using ethnic languages in schools, and administering locally-owned schools) have been perceived by the Bama-dominated government as acts of rebellion, tantamount to outright secession. However, the state's unwillingness to countenance the existence (let alone support the development) of locally owned education regimes may be changing. The Thein Sein government has been willing to envisage significant reforms in education, including elements of decentralisation. Discussion and reforms in regard to education policy and decentralisation have opened some space for mother tongue education in government schools - although not to the degree demanded by most ethnic and other education activists. What has not yet been considered in any depth however, is the relationship between state and non-state basic education provision in conflict-affected areas, and how this relates to the ongoing (if currently stalled) peace process. 
Ethnic nationalist (EAG, but also civil society and community-led) activities in the field of education are representative of broader struggles for self-determination. Ethnic responses to 'Burmanisation' and centralisation may be plotted along a continuum - ranging from demands for outright independence from a Union for which many ethnic people feel little sympathy (secession, or separatism), through varying forms of autonomy and decentralisation - varieties of (including 'asymmetric') federalism. At one end of this spectrum would be the 'Union Karen' (Thawnghmung 2008, South 2008) and other ethnic groupings, which while self-identifying with their ethnic community, nevertheless feel a degree of fairly strong association with the Union.

In relation to education, separatist agendas can be represented by schools featuring little or no Burmese language teaching, using a curriculum often radically different to that of the state, taught in local languages; a more federalist approach would be represented by the promotion of mother tongue in schools which also teach Burmese, and broadly follow the government curriculum (modified according to local contexts and conditions). In relation to school ownership and administration, the former positions demand locally-owned schools, administered by ethnic political authorities (EAGs, or otherwise); a more federalist approach could also imply non-state school ownership, but with a curriculum and regime linked to the government system - or could mean greater focus on mother tongue teaching (and instruction in appropriate local cultures and history) in schools which could nevertheless be part of the state system. In addition to the politics of these positions, important practical considerations remain regarding, for example accreditation.

Thus, positions in relation to education can be taken as proxies of different actors' views regarding a broader range of state-society issues, and the distribution of power and resources, actual and symbolic/cultural capital, between the central government and ethnic polities. In this framing, the NMSP (MNEC) model can be seen as achieving a fairly high degree of local self-determination in education, while retaining strong links to the (hopefully future federal) Union. This was previously the case with the KIO system, which under pressure of the resumption of armed conflict seems to be moving towards a more separatist model, similar to that adopted historically by the KNU (which itself may nevertheless be undergoing significant changes).

Similar mapping may be applied to positions in relation to language use and policy, in schools and in governance functions more broadly. Most stakeholders seem to accept the necessity (or desirability) of teaching children Burmese (Bama saga). All but the most diehard separatists among Myanmar's ethnic nationalists seem willing to concede the status of Burmese (Bama saga) as a national/Union language, or lingua franca (in some cases, together with English, due to its international status). The degree or manner in which Burmese and/or ethnic languages (with the emphasis on the plural, as explored below) should be used for public administration, government and legal processes are indicators of how different actors view the distribution of power between the (Burman) centre and (ethnic) periphery in a reforming Myanmar and might be taken as rough proxies for other sectors, for example in relation to natural resource management and revenue sharing and distribution, between the Union government and ethnic States. For example, those who seek to use ethnic languages as a primary medium of governance and administration in ethnic States can 
be expected to adopt strong/maximalist positions regarding the degree of natural resource revenue and other financial and political goods which should be retained at, and/or redistributed to, the local/State level (federalism) - and in extreme cases may argue for complete separation of the ethnic polities from the (rump) Union. Moderates may adopt positions according to which ethnic languages are used together with Burmese, or in a supplementary manner at the State level - corresponding to varying degrees of autonomy or decentralisation, including various forms of federalism. While such arguments are rarely explicit among ethnic educators, political activist more generally, exploring different positions in relation to language and education can help to reveal the kind of country people imagine Myanmar to be - and their hopes (and concerns) regarding the peace process, and broader political transition.

Within this discussion, further reflection is required on the position of 'minorities within minorities' - ethnic communities with different identities (usually reflected in different language uses) to those of the locally dominant minority (e.g. Kachin linguistic sub-groups, the variety of Karen ethno-linguistic communities), and their possible vulnerability in the context of a potentially totalizing dominant local ethnic/national identity. We hope to explore such issues in a future publication.

\section{Conclusion}

The positions of different stakeholders in relation to language policy and use (in schools, and governance) indicate positions regarding state-society conflict and possible outcomes, more broadly. Schooling in ethnic mother tongues is valuable in a multi-ethnic country like Myanmar, for both pedagogic and political reasons. Furthermore, non-state (EAG) education regimes are concrete examples of selfdetermination for ethnic nationality communities ('federalism from below'), in a context where elite-level political discussions around the peace process have yet to reach a sustainable conclusion.

Education regimes developed by (or under the authority of) EAGs are shaped by peace and conflict dynamics - tending to be more separatist in character when conflict is rife, and less separatist (more willing to engage, and perhaps integrate, with state systems) when ceasefires are in place. Therefore conflict and peace are key variables in shaping education policy and practice in ethnic areas, and education is also a key variable in the peace process. However, while current education reforms in Myanmar do address issues of mother tongue education and ethnic schooling, to a degree, these are largely disconnected from the peace process; likewise, key peace process (EAG and government leaders) have thus far paid little attention to issues of education or language. The forthcoming elections in Myanmar present opportunity to discuss these issues on the national political stage, and bring them onto the (crowded and contested) agenda of the future government. Ethnic political parties in Myanmar will have a particular role to play in this respect; EAGs and associated civil society actors will continue to be important providers of ethnic education, and should be encouraged to address these issues more in policy dialogue, and in peace negotiations. Peace in Myanmar will only be sustainable if durable solutions are found to language policy debates, and education is no longer used as a political tool. 


\section{References}

Bush, K., and Saltarelli D. (2000) 'Two Faces of Education in Ethnic Conflict." Innocenti Insight. UNICEF: Florence, Italy

Brock, C. (2011) "Education and Conflict: a fundamental relationship" Chapter One in Paulson, J. (ed) (2011) "Education, Conflict and Development" Oxford Studies in Comparative Education, Symposium Books Ltd, Oxford. pp. 17 - 31

Callahan, M. (2003) "Language Policy in Modern Burma", in M. Brown, and S. Ganguly (eds), Fighting Words, Language Policy and Ethnic Relations in Asia. Cambridge: MIT Press: 143-75

Houtman, G. (1999) "Mental Culture in Burmese Crisis Politics: Aung san Suu Kyi and the National League for Democracy". Monograph Series 33. Tokyo University of Foreign Studies, Institute for the Study of Languages and Cultures of Asia and Africa. Tokyo.

Joffe, K. (2014) Ethnic Armed Conflict and Territorial Administration in Myanmar, The Asia Foundation, Bangkok.

Lall, M. And South, A. (2013) 'Comparing models of non-state ethnic education in Myanmar: the Mon and Karen national education regimes', Journal of Contemporary Asia (published on line August 2013)

Lall, M. and Hla Hla Win (2013) Perceptions of the state and citizenship in light of the 2010 Myanmar elections in Skidmore, M. and Wilson, T. Myanmar's transition Openings, Obstacles and Opportunities, ISEAS, Singapore.

Lall, M. et al. (2014) Citizenship in Myanmar - contemporary debates and challenges in light of the reform process. Myanmar Egress and FNS, Yangon and Bangkok

Myanmar Peace Support Initiative. (2014) Lessons Learned from MPSI's work supporting the peace process in Myanmar (Yangon, March 2014)

Salem-Gervais, N. and Metro, R. (2012) "A Textbook Case of Nation-Building: The Evolution of History Curricula in Myanmar" Journal of Burma Studies. 16 (1): 27-78

Smith, M. (1999) Burma: insurgency and the politics of ethnicity. 2 ed. London: Zed Books.

Smith, A. and Vaux T. (2003) "Education, Conflict and International Development" DfID, London

South, A. (2008) Ethnic Politics in Burma: states of conflict. London: Routledge.

South, A. (2011) "Burma's Longest War: anatomy of the Karen conflict". Transnational Institute. Burma Centre Netherlands. Amsterdam. 
UNESCO (2011a) "EFA Global Monitoring Report. The hidden crisis: Armed conflict and education" UNESCO Publishing, Paris.

Watkins, J. Burma/ Myanmar in Simpson, A. (ed.) (2007) Language and National Identity in Asia. Oxford Linguistics. 